\title{
Diel periodicity in the photosynthetic capacity of coastal and offshore phytoplankton assemblages
}

\author{
Todd M. Kana ${ }^{1}$, Jennifer L. Watts ${ }^{2 *} \&$ Patricia M. Glibert ${ }^{1}$ \\ ${ }^{1}$ Woods Hole Oceanographic Institution, Woods Hole, Massachusetts 02543, USA \\ ${ }^{2}$ Department of Biology, University of California, Santa Barbara, Santa Barbara, California 93117, USA
}

\begin{abstract}
Diel changes in the photosynthetic-irradiance response of phytoplankton were measured in coastal, neritic and oceanic waters. At each site, maximum daily light-saturated photosynthesis rates were 2 to 3 times higher than rates recorded either at dawn or dusk. Time of day that maximum occurred varied with site and depth. Diel measurements in coastal water indicated that minimum photosynthetic capacity occurred in the middle of the night, that up to one-half of the total diel change occurred at night, and that times of most rapid change occurred around dawn and dusk. Independent measurements of nitrogen nutritional status on the neritic and oceanic assemblages indicated that there was no nitrogen limitation for phytoplankton growth.
\end{abstract}

\section{INTRODUCTION}

Photosynthetic capacity, defined as the light-saturated photosynthetic rate, has often been observed to undergo daily oscillations in natural assemblages of phytoplankton (cf. Doty \& Oguri 1957, Doty 1959, Malone 1971, MacCaull \& Platt 1977, Harding et al. 1982a). These oscillations invariably exhibit a maximum during the day and minimum at night and are independent of changes in chlorophyll a (chl a) concentration (Curl \& Small 1965, Newhouse et al. 1967). Although the oscillation has a period of $1 \mathrm{~d}$, the time of day at which the maximum photosynthetic capacity occurs, or phasing of the rhythm, has been shown to be quite variable for natural phytoplankton assemblages (Malone 1971, Harding et al. 1982a).

Although it is well recognized that diel periodicity in photosynthetic capacity is controlled at least in part by the biological clock of the cell (Hastings et al. 1961, Palmer et al. 1964), external or environmental factors may significantly alter the expression of this rhythm. For example, Malone (1971) reported a correlation between the timing of light-saturated photosynthesis, $\mathrm{P}_{\max }$ and the relative abundance of netplankton and nanoplankton as well as the availability of nutrients in coastal and offshore waters of the Pacific, suggesting that both species and nutritional effects may influence

\footnotetext{
- Currently serving in the Peace Corps, Costa Rica
}

the rhythmic response. Harding et al. (1981a, b) have recently shown that diel periodicity in photosynthetic capacity is an inherent characteristic of numerous, though not all, phytoplankton species growing under light: dark cycles and that the amplitude of the response may change with growth rate.

There are 2 areas of significance of diel periodicity in photosynthesis for phytoplankton ecologists. The first is the effect on calculations of primary productivity. It has been clearly demonstrated that the amplitude of the rhythm and time of day chosen to conduct measurements of photosynthesis or productivity relative to the timing of the maximum can significantly affect the result of primary production calculations (Harding et al. 1982b). This has become especially relevant given the current tendency for investigators to conduct short-term ( 1 to $4 \mathrm{~h}$ ) incubation experiments. Secondly, evidence indicates that the amplitude and/or phasing of the photosynthesis rhythm may reflect the physiological state and, in particular, the nutrient status of the phytoplankton cell, suggesting that a determination of the rhythmic response of natural phytoplankton assemblages can possibly provide information on the degree of environmental limitation of the assemblage.

We report here on diurnal and diel changes in photosynthesis in natural assemblages of phytoplankton from coastal, neritic, and oceanic waters: Great Harbor, Woods Hole, Massachusetts, the Grand Banks off 
Newfoundland, and the Gulf Stream. Nitrogen nutritional status of the phytoplankton of the Gulf Stream and Grand Banks stations was assessed using one of the approaches suggested by Glibert \& McCarthy (1984) and correlated with the photosynthetic periodicity.

\section{MATERIALS AND METHODS}

Studies of diel periodicity in waters off Woods Hole, Massachusetts were conducted during July 1983. Samples of surface water were collected by bucket off the NOAA dock in Great Harbor, filtered through $125 \mu \mathrm{m}$ mesh Nitex netting, and transported to the laboratory. Photosynthesis measurements were begun in the laboratory within 15 to $20 \mathrm{~min}$ of sample collection. Studies in the Gulf Stream and Grand Banks were conducted during a cruise of the R/V Oceanus in August 1983, from Woods Hole, Massachusetts, to St. Johns, Newfoundland. Experiments reported here were conducted over the course of several days while on drifting stations in the Gulf Stream (centered near $39^{\circ} 50^{\prime} \mathrm{N}, 56^{\circ} 00^{\prime} \mathrm{W}$ ) and the Grand Banks (centered near $44^{\circ} 33^{\prime} \mathrm{N}, 53^{\circ} 22^{\prime} \mathrm{W}$ ). Water samples were collected by Niskin bottle immediately prior to measurement of each photosynthesis-irradiance (P-I) response and filtered through $125 \mu \mathrm{m}$ mesh Nitex netting to remove large zooplankton. Two depths were sampled at each station: one near the surface and, in the Gulf Stream, in the deep chlorophyll maximum determined from results of a discrete sampling profile from 5 to $100 \mathrm{~m}$, and, on the Grand Banks, at a depth just above the thermocline. In the Gulf Stream these depths were 10 and $75 \mathrm{~m}$, corresponding to light intensities of 50 and $1 \% \mathrm{I}_{\circ}$, and in the Grand Banks were 5 and $20 \mathrm{~m}$, corresponding to 65 and $15 \% \mathrm{I}_{0}$ respectively.

The P-I response was measured by dividing each water sample among seven 0.4 or five 1.01 polycarbonate bottles positioned in compartments of a rectangular clear acrylic water tank. Temperature was maintained in the tank by a thermostatically controlled water bath for the Great Harbor experiments, and by flowing surface seawater for the shipboard experiments. Illumination was provided by a bank of lights (GE $120 \mathrm{~W}$ 'Miser' incandenscent floodlight) directed horizontally at the water bath. Excess illumination was attenuated by neutral density filters consisting of one or more layers of fiberglass window screen secured on the outside of the water bath. Light scatter between compartments was prevented by opaque baffles. This incubation device allowed for subsampling of a given container for time-course measurements of the photosynthetic response in any given water sample. Photosynthetically active radiation (quantum scalar irradiance) was measured inside each sample bottle with a submersible quantum probe with 4-pi collector (Biospherical Instruments; QSL-100). Spatial variation of light availability within the bottles was generally $<15 \%$. The mean intensity is reported here. Light intensity at the depth of sampling on the cruise stations was estimated using a Secchi disc at midday.

Photosynthesis was measured using the ${ }^{14} \mathrm{C}$ tracer (Steemann Nielsen 1952). Incubations were started by the addition of $25 \times 10^{-6} \mathrm{Ci} \mathrm{I}^{-1} \mathrm{H}^{14} \mathrm{CO}_{3}$ and terminated by filtration through $25 \mathrm{~mm}$ Whatman GF/F glass fiber filters under a vacuum differential of $<100$ $\mathrm{mm} \mathrm{Hg}$. Filters were rinsed with $\sim 40 \mathrm{ml}$ of filtered seawater after little $(<1 \mathrm{~s})$ or no intervening air exposure and fumed over concentrated $\mathrm{HCl}$ for $>45 \mathrm{~s}$. Independent controls revealed that this treatment removed essentially all residual inorganic ${ }^{14} \mathrm{C}$. Radioactivity on the filters was counted by placing filters in Filmware bags (Nalgene) with $3 \mathrm{ml}$ of ScintiVerse II (Fisher Scientific) scintillation cocktail and left to stand $10 \mathrm{~h}$ or more before counting in a Beckman LS-100 liquid scintillation counter. Previous studies (unpubl.) have shown that ScintiVerse II does not immediately penetrate GF/F filters resulting, initially, in incomplete contact of the fluor with the radioactive particulate material. This can often result in a significant loss in counting efficiency relative to that obtained after 6 to $10 \mathrm{~h}$ of soaking. Complete penetration and maximum counting efficiency occurred when the filter turned translucent. It has been our general practice to let samples stand for 0.5 to $1 \mathrm{~d}$ before counting. Specific activities were determined on $0.1 \mathrm{ml}$ of the sample in $10 \mathrm{ml}$ of ScintiVerse II and $0.05 \mathrm{ml}$ of phenethylamine.

Photosynthetic rates were calculated from the time course of 1 and $2 \mathrm{~h}$ subsamples after subtraction of the amount of ${ }^{14} \mathrm{C}$ taken up in a dark bottle. Dark uptake rates were generally $<5 \%$ of the maximum uptake rate in the light. For estimation of the change in the rate of photosynthesis in a single sample under light saturation, aliquots were removed at short intervals (20 to $30 \mathrm{~min}$ ) for $3 \mathrm{~h}$ and rates calculated from the increase in radioactivity between successive subsamples.

An assessment of the nitrogen nutritional status of the phytoplankton was made by caiculating the ratio of the velocity of ${ }^{15} \mathrm{NH}_{4}^{+}$uptake under substrate-saturating concentrations $\left(\mathrm{V}_{\text {sat }}\right)$ to the velocity of ${ }^{15} \mathrm{NH}_{4}^{+}$ uptake under trace concentrations ( $V_{\text {trace: }}$ Glibert \& McCarthy 1984). The estimate is based on the notion that when the ratio is close to one, the uptake rate of $\mathrm{NH}_{4}^{+}$after a trace enrichment of ${ }^{15} \mathrm{NH}_{4}^{+}$(typically $10 \%$ of the ambient $\mathrm{NH}_{4}^{+}$concentration) is close to maximal and thus the ambient $\mathrm{NH}_{4}^{+}$concentration is sufficient to saturate or nearly saturate the uptake capacity of the cell. Elevated ratios indicate that the ambient availability of $\mathrm{NH}_{4}^{+}$is insufficient to support the maximal 
uptake capacity of phytoplankton cells, and hence, the growth rate of the population may be nitrogen limited. In this study, uptake experiments at saturating concentrations were begun by the addition of $8 \mu \mathrm{g}$-atom $1^{-1}{ }^{15} \mathrm{NH}_{4}^{+}$, and those at trace concentrations by the addition of $0.03 \mu \mathrm{g}$-atom $\mathrm{l}^{-1}{ }^{15} \mathrm{NH}_{4}^{+}$in the Gulf Stream and $0.04 \mu$ g-atom $1^{-1}{ }^{15} \mathrm{NH}_{4}^{+}$in the Grand Banks. All incubations were begun within $0.5 \mathrm{~h}$ of sample collection, and all experiments were terminated after $2 \mathrm{~h}$ by filtration onto Whatman GF/F filters. The filters were rinsed with filtered seawater, dried, and ${ }^{15} \mathrm{NH}_{4}^{+}$incorporation into particulate material was determined by mass spectrometric analysis (McCarthy et al. 1977. Nevins \& McCarthy 1982).

Analysis of chl a in samples which had been filtered onto Whatman GF/F filters was according to the fluorometric technique of Strickland \& Parsons (1972). Sample analysis was within $2 \mathrm{~d}$ of sample collection; filters were stored frozen. Analyses of ambient $\mathrm{NH}_{4}^{+}$ concentration were conducted in triplicate within $1 \mathrm{~h}$ of sample collection according to Strickland \& Parsons (1972), modified for $5 \mathrm{ml}$ volumes (McCarthy \& Kamykowski 1972). Ambient $\mathrm{NO}_{3}^{-}$concentrations were determined according to Strickland \& Parsons (1972) after frozen storage for $3 \mathrm{wk}$.

\section{RESULTS}

\section{Great Harbor studies}

The 2 studies in Great Harbor were conducted 2 wk apart, at nearly the exact same phase of the tide. Ambient concentrations of $\mathrm{NH}_{4}^{+}$and $\mathrm{NO}_{3}^{-}$were $<0.50 \mu \mathrm{g}$-atom $\mathrm{l}^{-1}$, but varied considerably with time

Table 1 Concentrations of nitrogenous nutrients and chl $a$ in samples collected from Great Harbor in July 1983

\begin{tabular}{|ccccc|}
\hline $\begin{array}{c}\text { Sample } \\
\text { time }\end{array}$ & $\begin{array}{c}\text { Tempera- } \\
\text { ture }\left({ }^{\circ} \mathrm{C}\right)\end{array}$ & $\begin{array}{c}\mathrm{Chl} a \\
\left(\mu \mathrm{g} \mathrm{l}^{-1}\right)\end{array}$ & $\begin{array}{c}\mathrm{NH}_{4}^{+} \\
\left(\mu \mathrm{g} \text {-atom }{ }^{-1}\right)\end{array}$ \\
\hline $\begin{array}{c}\text { July } 12-131983 \\
0030\end{array}$ & & & & \\
0430 & 21 & 2.5 & $<0.03$ & 0.16 \\
0830 & 21 & 1.9 & 0.53 & 0.17 \\
1230 & 23 & 3.5 & 0.39 & 0.20 \\
1630 & 22 & 2.1 & 0.35 & 0.16 \\
2030 & 21 & 3.7 & $<0.03$ & 0.21 \\
July 271983 & & & & \\
0130 & 21 & 3.1 & 0.09 & 0.16 \\
0300 & 21 & 2.0 & 0.37 & 0.17 \\
0430 & 21 & 1.9 & 0.15 & 0.15 \\
0600 & 21 & 2.9 & 0.34 & 0.13 \\
0730 & 21 & 2.4 & 0.37 & 0.13 \\
0900 & 22 & 2.7 & 0.05 & 0.39 \\
\hline
\end{tabular}

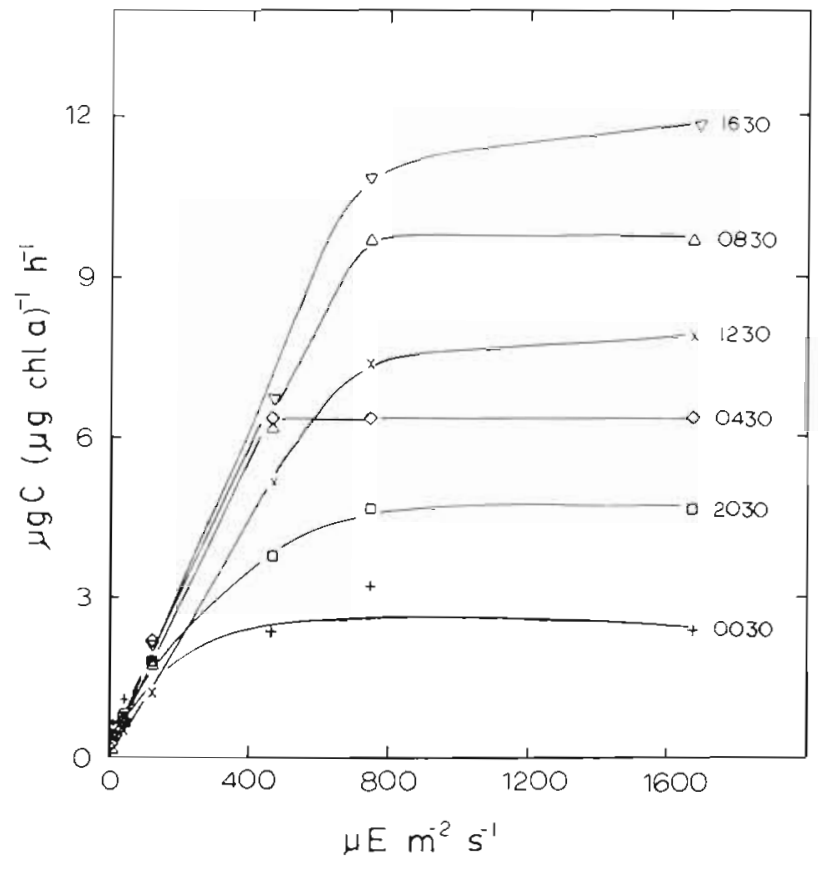

Fig. 1. Diel periodicity in the photosynthetic-irradiance relation for surface samples collected from Great Harbor, Massachusetts between 2030, July 12, and 1630, July 13 , 1983. Collection times (Eastern Daylight Time: EDT) indicated. Sunrise occurred at 0516 and sunset at 2020

of day (Table 1). Concentrations of chl a ranged from 1.9 to $3.7 \mu \mathrm{g} \mathrm{I}^{-1}$ (Table 1 ), and were approximately 1 to 3 times higher than previously reported for samples collected in July from a center-channel station in Vineyard Sound (Goldman et al. 1981, Glibert et al. 1985).

A $>4$-fold change in photosynthetic capacity was observed over the course of a 24 h period for a phytoplankton assemblage in Great Harbor on July 12 to 13 1983 (Fig. 1). A minimum light-saturated rate of $2.5 \mu \mathrm{g}$ $\mathrm{C}(\mu \mathrm{g} \mathrm{chl} \mathrm{a})^{-1} \mathrm{~h}^{-1}$ was measured shortly after midnight, and a maximum rate of $11.5 \mu \mathrm{g} \mathrm{C}(\mu \mathrm{g}$ chl a) ${ }^{-1} h^{-1}$ during mid-afternoon. A midday depression in photosynthetic capacity was observed in the 1230 sample relative to samples at 0830 and 1630 . Of the morning increase, approximately $50 \%$ of the rise occurred prior to dawn.

The pronounced increase in $\mathrm{P}_{\max }$ observed in the early morning hours on July 12 to 13 was reexamined on July 27 by collecting samples every $1.5 \mathrm{~h}$ from 0130 to 0900. With the exception of the P-I curves from the 0430 and 0600 samples which showed little difference, there was a steady rise in $P_{\max }$ from the first to the last sampling period (Fig. 2). The change was $>3$-fold over the $7.5 \mathrm{~h}$ sampling period, again with $\sim 50 \%$ of the increase occurring prior to dawn. The rates determined for samples collected at 0130,0430 , and 0900 very closely matched those for 0030, 0430 and 0830 determined on July 13. 


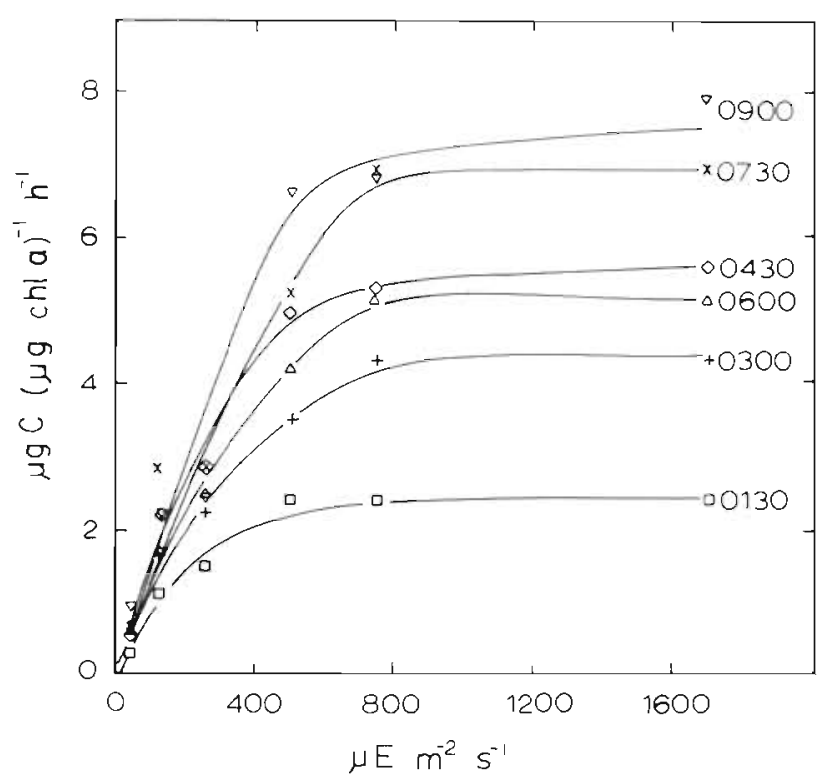

Fig. 2. Change in the photosynthetic-irradiance relation from $0300 \mathrm{~h}$ to $0900 \mathrm{~h}$ on July 27, 1983 for surface sample collected from Great Harbor, Massachusetts. Collection times (EDT)

indicated. Sunrise occurred at 0530 and sunset at 2006

The change in $\mathrm{P}_{\max }$ for July 27 was followed by collecting subsamples every $15 \mathrm{~min}$ from 0430 to 0600 and then at 0645 and 0700 from a single water sample under constant saturating light (Fig. 3). There was an increase in $\mathrm{P}_{\max }$ of $\sim 2.5$ fold during this $2.5 \mathrm{~h}$ period, but the most rapid change occurred after sunrise.

The change in the slope of the light-limited portion of the P-I curve $(\alpha)$ showed little discernible change during the course of the July 12 to 13 experiment although results from the experiment on July 27 did appear to show a tendency for $\alpha$ to increase with $\mathrm{P}_{\max }$ from 0130 to 0900 . Regression statistics were not calculated because of too few data points in the light-limited portion of the curve. The lowest intensity at which light saturation occurred was between 600 and $800 \mu \mathrm{E}$ $\mathrm{m}^{-2} \mathrm{~s}^{-1}$ for both sampling dates.

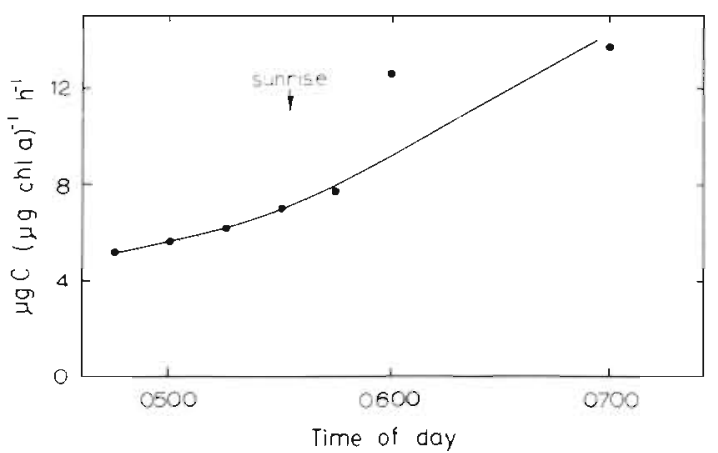

Fig. 3. Light-saturated $\left(1700 \mu \mathrm{E} \mathrm{m}^{-2} \mathrm{~s}^{-1}\right)$ photosynthesis rate as a function of time of day (EDT) for a surface sample collected from Great Harbor on July 27, 1983. See text for description of methodology

\section{Gulf Stream and Grand Banks studies}

For both the Gulf Stream and Grand Banks, ambient concentrations of $\mathrm{NH}_{4}^{+}$and $\mathrm{NO}_{3}^{-}$were, with 1 exception, above the analytical limits of detection $(0.03 \mu \mathrm{g}$ atom $\mathrm{l}^{-1}$ ). For $\mathrm{NH}_{4}^{+}$, however, these concentrations did not exceed $0.5 \mu \mathrm{g}$-atom $\mathrm{l}^{-1}$ (Table 2). Concentrations of $\mathrm{NO}_{3}^{-}$were 10 to 20 times greater at $75 \mathrm{~m}$ than at $10 \mathrm{~m}$ in the Gulf Stream, but in the Grand Banks, $\mathrm{NO}_{3}^{-}$ concentrations at 5 and $20 \mathrm{~m}$ were comparable (Table 2). Concentrations of chl a (Table 2) were relatively constant on a diel basis for each depth sampled, with approximately $0.05 \mu \mathrm{g} \mathrm{chl} \alpha^{-1}$ at $10 \mathrm{~m}$ and $0.35 \mu \mathrm{g} \mathrm{chl} \mathrm{a}^{-1}$ at $75 \mathrm{~m}$ in the Gulf Stream, and $\sim 0.17 \mu \mathrm{gchl} \mathrm{al^{-1 }}$ and 0.22 to $0.33 \mu \mathrm{g} \mathrm{chl} \mathrm{a} \mathrm{l}^{-1}$ at 5 and $20 \mathrm{~m}$ respectively in the Grand Banks.

As was the case for phytoplankton in Great Harbor, the photosynthetic capacity of phytoplankton from 10 and $75 \mathrm{~m}$ in the Gulf Stream depended on the time of day that the sample was collected (Fig. $4 \mathrm{~A}, \mathrm{~B}$ ). For the $10 \mathrm{~m}$ sample $\left(50 \% \mathrm{I}_{0}\right)$, the maximum photosynthetic capacity measured occurred between approximately 0900 and 1330. Measurements made at dawn and dusk indicated that $P_{\max }$ was $-30 \%$ of the rate attained $4 \mathrm{~h}$ after dawn or $4 \mathrm{~h}$ before dusk. For the $75 \mathrm{~m}$ sample, the maximum photosynthetic capacity also occurred $\sim 4 \mathrm{~h}$ after dawn, yet there was a slight decline in $P_{\max }$ by early afternoon (note scale change from Fig. 4 A to $4 \mathrm{~B}$ ). In sharp contrast to the data from the $10 \mathrm{~m}$ sample

Table 2. Concentrations of nitrogenous nutrients and chl a of samples collected in the Gulf Stream and Grand Banks

\begin{tabular}{|c|c|c|c|c|c|}
\hline Time & $\begin{array}{l}\text { Depth } \\
\text { (m) }\end{array}$ & $\begin{array}{l}\text { Temp. } \\
\left({ }^{\circ} \mathrm{C}\right)\end{array}$ & $\begin{array}{c}\text { Chl a } \\
\left(\mu \mathrm{g} \mathrm{l}^{-1}\right)\end{array}$ & $\begin{array}{l}\mathrm{NH}_{4}^{+} \\
(\mu \mathrm{g}-\mathrm{a}\end{array}$ & tom l-1) \\
\hline \multicolumn{6}{|c|}{ Gulf Stream } \\
\hline 0450 & $\begin{array}{l}10 \\
75\end{array}$ & $\begin{array}{l}27 \\
23\end{array}$ & $\begin{array}{l}0.06 \\
0.34\end{array}$ & $\begin{array}{r}0.18 \\
<0.03\end{array}$ & $\begin{array}{l}0.06 \\
1.21\end{array}$ \\
\hline 0900 & $\begin{array}{l}10 \\
75\end{array}$ & $\begin{array}{l}26 \\
23\end{array}$ & $\begin{array}{l}0.05 \\
0.22\end{array}$ & $\begin{array}{l}0.04 \\
0.09\end{array}$ & $\begin{array}{l}0.10 \\
1.65\end{array}$ \\
\hline 1330 & $\begin{array}{l}10 \\
75\end{array}$ & $\begin{array}{l}27 \\
24\end{array}$ & $\begin{array}{l}0.04 \\
0.33\end{array}$ & $\begin{array}{l}0.29 \\
0.21\end{array}$ & $\begin{array}{l}0.06 \\
1.28\end{array}$ \\
\hline 1800 & $\begin{array}{l}10 \\
75\end{array}$ & $\begin{array}{l}27 \\
23\end{array}$ & $\begin{array}{l}0.04 \\
0.35\end{array}$ & $\begin{array}{l}0.14 \\
0.11\end{array}$ & $\begin{array}{l}0.06 \\
0.54\end{array}$ \\
\hline \multicolumn{6}{|c|}{ Grand Banks } \\
\hline 0345 & $\begin{array}{r}5 \\
20\end{array}$ & $\begin{array}{l}18 \\
15\end{array}$ & $\begin{array}{l}0.17 \\
0.33\end{array}$ & $\begin{array}{l}0.15 \\
0.15\end{array}$ & $\begin{array}{l}0.04 \\
0.05\end{array}$ \\
\hline 0820 & $\begin{array}{r}5 \\
20\end{array}$ & $\begin{array}{l}18 \\
18\end{array}$ & $\begin{array}{l}0.15 \\
0.22\end{array}$ & $\begin{array}{l}0.10 \\
0.04\end{array}$ & $\begin{array}{l}<0.03 \\
<0.03\end{array}$ \\
\hline 1300 & $\begin{array}{r}5 \\
20\end{array}$ & $\begin{array}{l}19 \\
18\end{array}$ & $\begin{array}{l}0.18 \\
0.34\end{array}$ & $\begin{array}{l}0.06 \\
0.05\end{array}$ & $\begin{array}{l}0.07 \\
0.09\end{array}$ \\
\hline 1645 & $\begin{array}{r}5 \\
20\end{array}$ & $\begin{array}{l}18 \\
17\end{array}$ & $\begin{array}{l}0.18 \\
0.23\end{array}$ & $\begin{array}{l}0.38 \\
0.47\end{array}$ & $\begin{array}{l}0.08 \\
0.05\end{array}$ \\
\hline
\end{tabular}




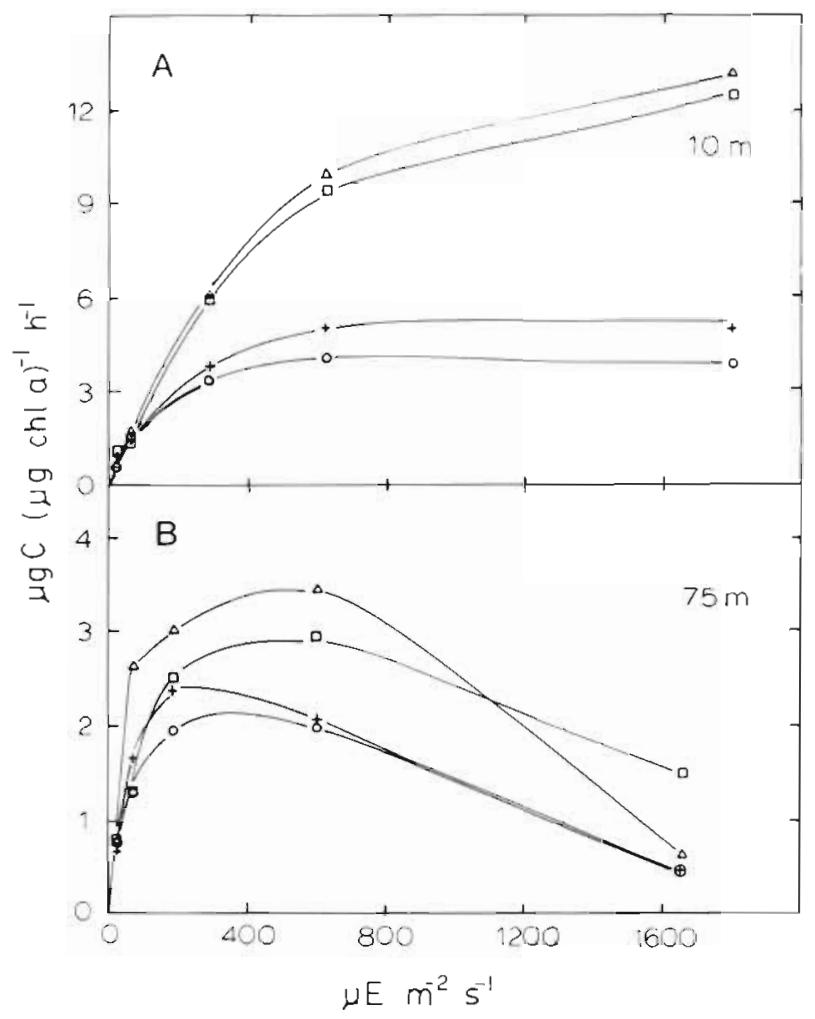

Fig. 4. Diurnal change in the photosynthetic-irradiance relation for samples from (A) $10 \mathrm{~m}$ and (B) $75 \mathrm{~m}$ in the Gulf Stream. Experiments conducted on August 18, 1983. Times of sample collection (EDT) were $0430(0), 0900(\Delta), 1330(\square)$, and $1800(+)$. Sunrise occurred at 0520 and sunset at 1845

in which light saturation of photosynthesis occurred at light intensities of $700 \mu \mathrm{E} \mathrm{m} \mathrm{m}^{-2} \mathrm{~s}^{-1}$ or greater, photosynthesis in the $75 \mathrm{~m}$ sample was light saturated in the range 300 to $600 \mu \mathrm{E} \mathrm{m}^{-2} \mathrm{~s}^{-1}$ and photoinhibited at

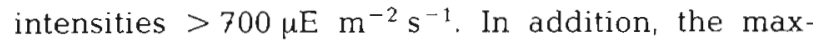
imum value of $\alpha$ from the $75 \mathrm{~m}$ sample was significantly greater than that observed in the $10 \mathrm{~m}$ sample.

Experiments were not conducted on samples below the $15 \% \mathrm{I}_{\mathrm{o}}$ light depth on the Grand Banks station due to a strong thermocline beginning at $20 \mathrm{~m}$ and our inability to cool the incubator below the temperature of surface seawater. Although samples from 5 and $20 \mathrm{~m}$ were analyzed, photosynthesis rates of corresponding

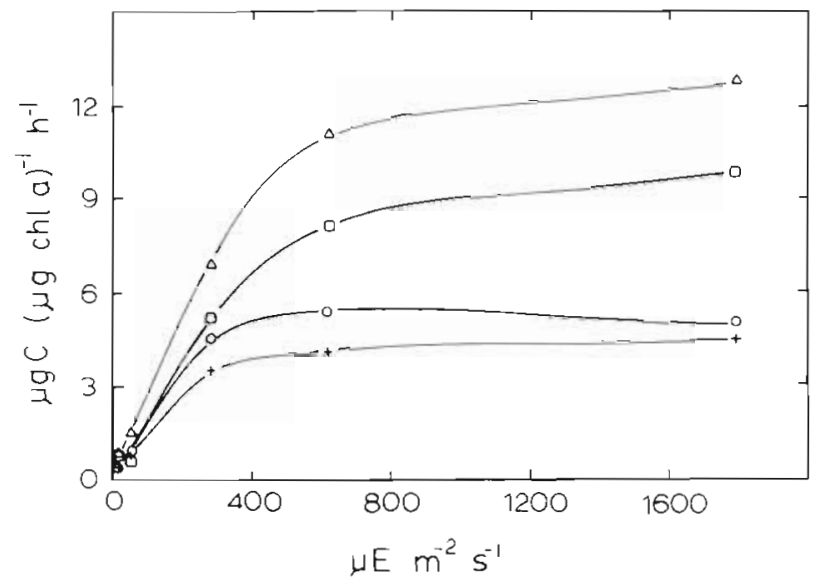

Fig. 5. Diurnal change in photosynthetic-irradiance relation for samples collected from $5 \mathrm{~m}$ at the Grand Banks station. Experiments conducted between 1645, August 23, and 1300, August 24, 1983. Times of sample collection (EDT) were 0345 $(0), 0820(\triangle), 1300(\square)$, and $1645(+)$. Sunrise occurred at 0430 and sunset at 1835

measurements did not differ by $>10 \%$. Therefore, only the $5 \mathrm{~m}\left(50 \% \mathrm{I}_{0}\right)$ results are presented here.

Diurnal changes in the photosynthetic capacity of phytoplankton from the Grand Banks station were also apparent with minimum (and nearly equivalent) rates recorded at dawn and dusk and maximum rates recorded $\sim 4 \mathrm{~h}$ after sunrise (Fig. 5). There was a decline of $\sim 20 \%$ in $\mathrm{P}_{\max }$ during the $4.5 \mathrm{~h}$ interval from the morning to afternoon measurements. Overall, there was an observed 3 -fold change in $P_{\max }$ over the course of the diurnal period. Fig. 6 shows the change in $P_{\max }$ for samples collected before dawn and prior to sunset with each subsampled every $30 \mathrm{~min}$ for $3 \mathrm{~h}$. The dawn sample is the same as that included in Fig. 5, whereas the evening sample was collected $1 \mathrm{~d}$ after the evening sample measured for the P-I study. The photosynthetic rate calculated from each interval increased from 3.7 to $10.5 \mu \mathrm{g} \mathrm{C}(\mu \mathrm{g} \mathrm{chl} \mathrm{a})^{-1} \mathrm{~h}^{-1}$ for the $3 \mathrm{~h}$ period just after dawn. This corresponded to the change observed in freshly collected samples at either end of the $3 \mathrm{~h}$ inter$\mathrm{val}$. During the $3 \mathrm{~h}$ period prior to sunset, $\mathrm{P}_{\max }$ declined $\sim 30 \%$. Changes in $\alpha$ over the course of the day
Fig. 6. Light-saturated $\left(1700 \mu \mathrm{E} \mathrm{m}^{-2} \mathrm{~s}^{-1}\right)$ photosynthesis rate as a function of time of day (EDT) for samples collected from $5 \mathrm{~m}$ at the Grand Banks station on August 24, 1983. See text for description of methodology

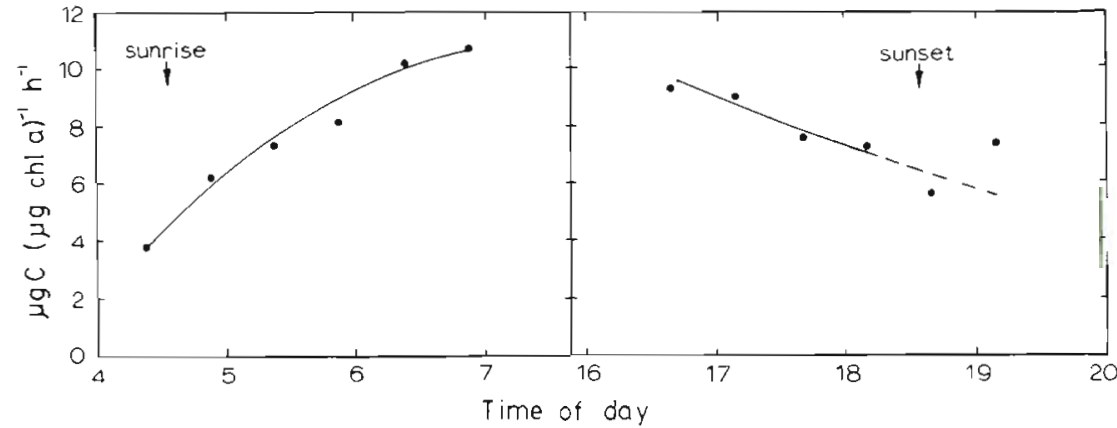


Table 3. Ammonium uptake velocities for trace and saturating enrichments in the Gulf Stream and Grand Banks stations

\begin{tabular}{|cccc|}
\hline $\begin{array}{c}\text { Depth } \\
(\mathrm{m})\end{array}$ & $\begin{array}{c}\text { Enrichment } \\
\left(\mu \mathrm{g} \text {-atom } \mathrm{l}^{-1}{ }^{15} \mathrm{NH}_{4}^{+}\right)\end{array}$ & $\mathrm{V}\left(\mathrm{h}^{-1}\right)$ & $\mathrm{V}_{\text {sat }} / \mathrm{V}_{\text {trace }}$ \\
\hline \multicolumn{4}{c}{ Gulf Stream } \\
10 & 8.00 & 0.0128 & 1.7 \\
& 0.03 & 0.0074 & \\
75 & 8.00 & 0.0070 & 1.0 \\
& 0.03 & 0.0067 & \\
& \multicolumn{4}{c}{ Grand Banks } \\
5 & 8.00 & 0.0177 & 1.5 \\
& 0.04 & 0.0121 & \\
& &
\end{tabular}

appeared to parallel those of $\mathrm{P}_{\max }$ but, as with the previous data, there are too few points in the lightlimited region to resolve significant differences in $\alpha$.

Uptake rates of $\mathrm{NH}_{4}^{+}$at trace and saturating concentrations were determined at midday in the Gulf Stream and Grand Banks (Table 3). The ratio $V_{\text {sat }} / V_{\text {trace }}$ for $\mathrm{NH}_{4}^{+}$uptake was 1.7 and 1.0 for the 10 and $75 \mathrm{~m}$ Gulf Stream samples respectively, and 1.5 for the $5 \mathrm{~m}$ Grand Banks station.

\section{DISCUSSION}

\section{Diel vs diurnal changes in $P_{\max }$}

Diel changes in photosynthetic capacity were pronounced in each of the 3 sites with 2 - to 3 -fold changes in $\mathrm{P}_{\max }$ occurring between dawn and dusk, but with the P-I response recorded at dawn nearly identical to that recorded at dusk. Great Harbor was the only site for which samples were collected at frequent intervals during the dawn and dusk periods (Fig. 1 \& 2), and from these data it appears that changes in photosynthetic capacity were occurring rapidly during these 2 times of day, with up to half of the total diel change occurring at night. This pattern is similar to that described by Prézelin \& Ley (1980), who also showed that a nearly equivalent amount of change in photosynthetic capacity occurred during the nocturnal period as during the diurnal period. The general pattern of the diel photosynthesis response that emerges from this and other studies (Stross et al. 1973, Prézelin \& Ley 1980, Harding et al. 1982a) is that of an oscillation with relatively narrow (few hours) peaks during the day and troughs during the night, and rapid directional changes around sunrise and sunset. We have shown that the changes in $P_{\max }$ around dawn and dusk can be significant and occur independent of naturally changing light intensity (Fig. 3 \& 6).

We feel that there are several reasons to explicitly distinguish between diel (24 h) and diurnal (dawn to dusk) changes in photosynthesis, despite some problems associated with defining cut-off periods at times of rapid change. First, even though the magnitude of the change at night may be as great as the magnitude during the day, the ecological significance of the nocturnal component does not equal that of the diurnal component since photosynthesis in the natural environment is a diurnal process. The distinction, therefore, is based on the natural temporal cut-off periods for photosynthesis. Measurement of the diurnal rhythm of photosynthesis would be sufficient for calculations of primary production and, we believe, assessments of environmental effects on carbon assimilation. It still remains to be determined, however, whether the nocturnal portion of the rhythm is linked to or is correlated with other physiological processes such as nutrient uptake or assimilation capacity which might also be indicative of the physiological state of the phytoplankton.

The second reason for distinguishing between diel and diurnal changes in photosynthesis is to emphasize that a commonly used measure for comparing photosynthetic rhythms, the amplitude, is contingent upon making measurements which coincide with the actual maximum and minimum of the cycle. Satisfying such a requirement in order to obtain an accurate measurement of the amplitude is often not practical, particularly during extended sampling periods or when only limited assistance is available for frequent sampling. We advocate that as a basic minimum, the diurnal amplitude be measured by sampling at dawn and dusk and several times during the daylight period. Unfortunately, few reports on natural photosynthetic periodicity have included dawn-to-dusk measurements or, as importantly, included the time of sampling relative to dawn and dusk. We feel that these inclusions or notations are important because rates measured as few as 1 to 2 h after dawn or before dusk can be significantly higher than rates measured at dawn or dusk.

\section{Environmental regulation of the photosynthesis rhythm}

Our measurements of diurnal changes in photosynthesis showed differences among sites in both the amplitude and timing of the response. As has been shown previously for natural phytoplankton assemblages, the consistent morning increases and afternoon decreases that were observed were independent of in situ changes in chl a concentration (Curl \& Small 1965, Newhouse et al. 1967). In addition, we have found that the magnitude of the diurnal change was not directly correlated with the average chl a concentration of the 
water, as chl a was up to 2 orders of magnitude more concentrated in Great Harbor than in the surface water of the Gulf Stream, yet the amplitude of the diurnal change in photosynthesis was lower in Great Harbor by approximately one-third.

Diurnal amplitudes were greatest in the surface samples of the Gulf Stream and Grand Banks, and approximately one-third lower in Great Harbor and at the $1 \%$ light depth in the Gulf Stream site. These amplitudes are within the range of values reported for coastal surface water off Japan (Taguchi 1976), California (Prézelin \& Ley 1980, Harding et al. 1982a), eastern Canada (MacCaull \& Platt 1977), and eastern Australia (Jitts 1965). The differences in amplitude of $P_{\max }$ noted between our study sites may have been due to one or more of a number of possibilities, including differences in nutritional status of the assemblages, differences among sites in species composition and associated species differences in diel response, or, in 1 case, depth-dependent differences associated with being isolated below the surface mixed layer.

The influence of phytoplankton nutrient status on the magnitude and timing of the diel photosynthetic rhythm has been previously proposed (Malone 1971, Stross et al. 1973, Harding et al. 1981b), but has not been directly field tested to date with independent assessments of nutritional status. It is generally assumed that nutritionally stressed phytoplankton assemblages would display a dampened oscillation relative to that of nutrient replete phytoplankton. We have only independent estimates of the nitrogen nutritional status for the Gulf Stream and Grand Banks stations. For each of these, the ratio of $\mathrm{V}_{\text {sat }} / \mathrm{V}_{\text {trace }}\left(\mathrm{NH}_{4}^{+}\right)$ was consistently $<2$ (Table 3 ), which suggests that ambient concentrations of $\mathrm{NH}_{4}^{+}$were sufficient to support growth requirements for nitrogen (Glibert \& McCarthy 1984). We believe, however, that a generalization concerning the nitrogen nutritional status of a natural phytoplankton assemblage based on only 1 index of nutritional status should be tentative (Glibert \& McCarthy 1984), although, in support of our above conclusion, there have been no reported examples to date of a nitrogen limited assemblage which exhibits a $\mathrm{V}_{\text {sat }} / \mathrm{V}_{\text {irace }}\left(\mathrm{NH}_{4}^{+}\right)$ratio near 1 .

For Great Harbor, no comparable $\mathrm{V}_{\text {sat }} / \mathrm{V}_{\text {trace }}\left(\mathrm{NH}_{4}^{+}\right)$ data are available for this period of sampling. However, extensive studies on nitrogen nutrition and primary productivity of Vineyard Sound (adjacent to Great Harbor) phytoplankton have revealed that these phytoplankton are generally not nitrogen limited, except during the summer when a moderate degree of nitrogen nutritional stress has been observed (Glibert et al. 1982, Glibert et al. 1985). These summer-time occurrences correspond to short and sporadic phytoplankton blooms. The high chl a concentration in
Great Harbor during our period of sampling (Table 1) would be suggestive that such a bloom was occurring (previous comparisons have revealed no significant differences in chl a concentrations between Great Harbor and Vineyard Sound: unpubl.), but this remains speculative. However, based on previous seasonal studies of this area (Glibert et al. 1982, Glibert et al. 1985), the nitrogen nutrient concentrations of Great Harbor measured during the present study would not indicate a nitrogen-limited condition. Thus, it is unlikely that nutritional factors alone can explain the difference in amplitude of $\mathrm{P}_{\max }$ observed for our 3 sites. Yet, it is clear that additional measurements covering a broader range of nutritional states are needed before we can critically evaluate any effect of nutritional state on the amplitude or timing of the diurnal photosynthetic oscillations.

The lower amplitude of the diurnal oscillation exhibited by the deep $(75 \mathrm{~m})$ assemblage in the Gulf Stream relative to the near surface $(10 \mathrm{~m})$ assemblage (Fig. 4) could have been due to either species-specific differences, the effect of which has been demonstrated by Harding et al. (1981a), or differences in environmental variables, such as lower ambient growth light intensities. We do not believe that the 3 to $4 \mathrm{C}^{\circ}$ difference in temperature was great enough to cause the lower $\mathrm{P}_{\max }$ and amplitude in the deep assemblage (Steemann Nielsen \& Jorgensen 1968, Steemann Nielsen 1975). In previous studies in which the periodicity of photosynthesis from surface samples has been compared with that from deeper samples (Doty \& Oguri 1957, McAllister 1963, Sournia 1967, Taguchi 1976), there has typically been little difference noted (Doty \& Oguri 1957, Taguchi 1976). However, in these studies there was not enough information supplied to rule out the possibility that the samples were not all obtained within the surface mixed layer. We are confident that the $75 \mathrm{~m}$ sample in our study was isolated from the surface mixed layer, because it had significantly higher chl $a$ and $\mathrm{NO}_{3}^{-}$concentrations than the comparable near-surface sample. Our results are consistent with those of McAllister (1963) and Sournia (1967) in that decreasing amplitude of the diel variation occurred with increasing depth, but clearly too few observations have been made of photosynthetic periodicity at different depths of a water column to determine whether this decrease is a general phenomenon and, if so, what the causative factors are.

\section{The midday depression in $P_{\max }$}

The diurnal pattern of the P-I response observed in Great Harbor (Fig. 1) showed a pronounced midday depression. This pattern was similar to one of the 
observations of Harding et al. (1982a) on southern California coastal assemblages. Whereas the midday depression in $\mathrm{P}_{\max }$ is most typically attributed to photoinhibition of photosynthesis (Harris 1980), it seems that in our study, photoinhibition was not the direct cause of the midday depression that we observed. The highest experimental light intensities used were equivalent to midday in situ surface irradiances and no inhibition at the highest intensities was observed at any time of the day (Fig. $1 \& 2$ ). The presumed environmental control of this midday depression in photosynthetic capacity may reside in enhanced photorespiration at midday, as the photosynthesis pattern is similar to that described by Harris \& Piccinin (1977).

Thus, while the results of these studies and others have revealed that periodicity in photosynthesis is nearly universal for marine phytoplankton, much more work is needed to understand the environmental and physiological regulation of these rhythms. If a direct relation between algal nutritional status and amplitude or phasing of the rhythm can be established, then measurements of periodicity in photosynthesis could be used diagnostically in identifying nutritional status of a natural assemblage.

Acknowledgements. This work was supported by a Mellon Study Award to P. M. G., and by a Woods Hole Oceanographic Summer Student Fellowship to J. L. W We thank L. P. Madin for ship-time, and J. J. McCarthy for use of his mass spectrometer. Contribution no. 5873 from the Woods Hole Oceanographic Institution.

\section{LITERATURE CITED}

Curl, H. C., Small, L. F. (1965). Variations in photosynthetic assimilation ratios in natural marine phytoplankton communities. Limnol. Oceanogr. 10: (Suppl.) R67-R73

Doty, M. S. (1959). Phytoplankton photosynthesis periodicity as a function of latitude. J. mar. biol. Ass. India 1: 66-68

Doty, M. S., Oguri, M. (1957). Evidence for a photosynthetic daily periodicity. Limnol. Oceanogr. 2: 37-40

Glibert, P. M., Goldman, J. C., Carpenter, E. J. (1982). Seasonal variations in the utilization of ammonium and nitrate by phytoplankton in Vineyard Sound, Massachusetts, USA. Mar. Biol. 70: 237-249

Glibert, P. M., McCarthy, J. J. (1984). Uptake and assimilation of ammonium and nitrate by phytoplankton: indices of nutritional status for natural assemblages. J. Plankton Res. 6: $677-697$

Glibert, P. M., Dennett, M. R., Goldman, J. C. (1985). Inorganic carbon uptake by phytoplankton in Vineyard Sound, Massachusetts: II. Comparative primary productivity and nutritional status of winter and summer assemblages. J. exp. mar Biol. Ecol. 86: 101-118

Goldman, J. C., Taylor, C. D., Glibert, P. M. (1981). Nonlinear time-course uptake of carbon and ammonium by marine phytoplankton. Mar. Ecol. Prog. Ser 6: 137-148

Harding, L. W Jr., Meeson, B. W., Prézelin, B. B., Sweeney, B. M. (1981a). Diel periodicity of photosynthesis in marine phytoplankton. Mar Biol. 61.95-105
Harding, L. W. Jr., Prézelin, B. B., Sweeney, B. M., Cox, J. L. (1981b). Diel oscillations in the photosynthesis-irradiance relationship of a planktonic marine diatom. J. Phycol. 17: 389-394

Harding, L. W. Jr., Prézelin, B. B., Sweeney, B. M., Cox, J. L. (1982a). Diel oscillations of the photosynthesis-irradiance (P-I) relationship in natural assemblages of phytoplankton. Mar. Biol. 67: 167-178

Harding, L. W. Jr., Prézelin, B. B., Sweeney, B. M., Cox, J. L. (1982b). Primary production as influenced by diel periodicity of phytoplankton photosynthesis. Mar. Biol. 67: 179-186

Harris, G. P. (1980). The measurement of photosynthesis in natural populations of phytoplankton. In: Morris, I. (ed.) The physiological ecology of phytoplankton. Univ. California Press, Berkeley, p. 129-187

Harris, G. P., Piccinin, B. B. (1977). Photosynthesis by natural phytoplankton populations. Arch. Hydrobiol. 80: 405-457

Hastings, J. W., Astrachen, L., Sweeney, B. M. (1961). A persistent daily rhythm in photosynthesis. J. gen. Physiol. 45: $69-76$

Jitts, H. R. (1965). The summer characteristics of primary productivity in the Tasman and Coral seas. Aust. J. mar. Freshwat. Res. 16: 151-162

MacCaull, W. A., Platt, T. (1977). Diel variations in the photosynthetic parameters of coastal marine phytoplankton. Limnol. Oceanogr. 22: 723-731

Malone, T. C. (1971). Diurnal rhythms in netplankton and nanoplankton assimilation ratios. Mar. Biol. 10: 285-289

McAllister, C. D. (1963). Measurements of diurnal variation in productivity at ocean station ' $\mathrm{P}$ '. Limnol. Oceanogr. 8: 289-292

McCarthy, J J., Kamykowski, D. (1972). Urea and other nitrogenous nutrients in La Jolla Bay during February, March and April 1970. Fish. Bull. U.S. 70: 1261-1274

McCarthy, J. J., Taylor, W. R., Taft, J. L. (1977). Nitrogenous nutrition of the plankton in the Chesapeake Bay. I. Nutrient availability and phytoplankton preferences. Limnol. Oceanogr. 22: 996-1011

Nevins, J. L., McCarthy, J. J. (1982). ${ }^{15} \mathrm{~N}$ tracer studies in marine ecosystems. Nuclide Spectra (Tech. Publ.), State College, Pensylvania, Vol. XV

Newhouse, J., Doty, M. S., Tsuda, R. T. (1967). Some diurnal features of a neritic surface plankton population. Limnol. Oceanogr. 12: 207-212

Palmer, J. D., Livingston, L., Zusy, F. D. (1964). A persistent diurnal rhythm in photosynthetic capacity. Nature, Lond. 203: $1087-1088$

Prézelin, B. B., Ley, A. C. (1980). Photosynthesis and chlorophyll a fluorescence rhythms of marine phytoplankton. Mar. Biol. 55: 295-30?

Sournia, A. (1967). Rhythme nycthéméral du rapport 'intensité photosynthétique/chlorophylle' dans le plancton marin. Compt. rend. hebd. Séances Acad. Sci. Serie D. 265: 1000-1003

Steemann Nielsen, E. (1952). The use of radioactive carbon $\left(\mathrm{C}^{14}\right)$ for measuring organic production in the sea. J. Cons. int. Explor. Mer 18: 117-140

Steemann Nielsen, E. (1975). Marine photosynthesis with special emphasis on the ecological aspects. Elsevier Oceanogr. Ser. 13. Elsevier, Amsterdam

Steemann Nielsen, E., Jorgensen, E. G. (1968). The adaptation of plankton algae. I. General part. Physiologia Pl. 21. $401-413$

Strickland, J. D., Parsons, T. R. (1972). A practical handbook of seawater analysis, 2nd ed. Bull. Fish. Res. Bd Can. 167 
Stross, R. G., Chisholm, S. W., Downing, T. A. (1973). Causes of daily rhythms in photosynthetic rates of phytoplankton. Biol. Bull. mar. biol Lab., Woods Hole 145: 200-209
Taguchi, S. (1976). Short-term variability of photosynthesis in natural marine phytoplankton populations. Mar. Biol. 37: $197-207$

This paper was submitted to the editor; it was accepted for printing on June 10, 1985 